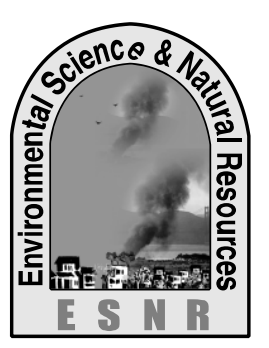

\title{
Impacts of Some Climatic Variables on the Seasonal Productivity of Aman Rice at Dhaka Region, Central Part of Bangladesh
}

\author{
S. M. S. A. Tuhin*, M. A. Farukh, B. S. Nahar and M. A. Baten \\ Department of Environmental Science, Bangladesh Agricultural University \\ Mymensingh-2202 \\ *Corresponding author: tuhin505@gmail.com
}

\begin{abstract}
An agro-climatic study was conducted at Dhaka region of Bangladesh using 43 years (1970-2012) of climatic data (daily maximum temperature, seasonal total rainfall, daily average humidity, and daily sunshine hour) to observe the climatic variability and their impacts on the productivity of Aman rice. The average maximum temperature increased by $0.04^{\circ} \mathrm{C}$ in $A m a n$ season in Dhaka region. The average sunshine hours decreased by 0.05 in the season. The average humidity decreased by $0.14 \%$ in the season. The average seasonal rainfall increased slightly by $0.09 \mathrm{~mm}$ in the season. The Aman rice production increased by $0.03 \mathrm{t} \mathrm{ha}^{-1}$ in the region. The production year 2003 shows highest productivity due to less climatic devastation impact on the seasonal productivity of the rice. The climatic variables impact ( $S_{\text {avg }}>H_{\text {avg }}>T_{\max }$ ) implies the seasonal productivity of Aman rice was mostly and inversely correlated with average sunshine $\left(S_{\text {avg }}\right)$ hour. However, most of the time the production showed increasing trend except some devastating natural calamities in the year of 1988 and 1998 which affected crop production seriously.
\end{abstract}

Key words: Aman rice, Climatic variables, Seasonal productivity

\section{Introduction}

Bangladesh is a country of divergent climatic conditions through the year mainly for its geographic location and physiographic condition. Agriculture of this country, irrigated and rain fed, is inherently vulnerable to climatic hazards. Rice is the staple food for above 150 million population whereas, the population growth rate is 2 million per year (Basak et al., 2009). Climatic factors such as temperature, rainfall, solar radiation, humidity etc. are closely linked with agricultural production. Therefore, rice production would be a major concern in recent years due to changing climatic conditions, because a significant amount of rice yield may hamper only for fluctuations of some climatic parameters. Temperature greatly influences not only the growth duration, but also the growth pattern and the productivity of rice crops. During the growing season, the mean temperature and the temperature sum, range and distribution pattern, and diurnal changes or combination of these may be highly correlated with grain yields (Basak et al., 2009). The solar radiation requirement of a rice crop differs from one growth stage to another. Shading during the reproductive and ripening phases cause significant reduction in yield (Islam and Morison, 1992). Increase in sunshine hour increases rice yield to some extent (Basak et al., 2009). Relative humidity is also important which may affect grain formation, ripening and disease incidence in rice. High relative humidity favors crop growth through the vegetative stage (Amin et al., 2004). Rainfall can vary considerably even within few distance and different variable over space and time (Adejuwon, 2004). Under the ongoing climate change conditions yield reduction of over $20 \%$ and $50 \%$ have been predicted for the years 2050 and 2070, respectively (Basak et al., 2010). Karim et al. (1996) argued that a significant yield reduction (35\%) may occur in rice due to changing climatic conditions in the future. This research work deals with the influence of temperature, sunshine, humidity and rainfall on seasonal productivity of Aman rice at Dhaka division. Past records prevailed a very few studies has been done to analyze the relationship between climatic parameter and Aman rice production at the Dhaka region. Under these circumstances this piece of research was conducted to observe a long term trend of climatic variables at Dhaka region and to observe the impact of studied climatic variables on seasonal productivity of Aman rice.

\section{Materials and Methods}

\section{Study area}

Analyses of climatology at regional scale are most useful for the solution of practical agricultural problems. Dhaka, the central part of Bangladesh, is situated at $23.79^{\circ} \mathrm{N}, 9030^{\circ} \mathrm{E}$ coordinate. According to BBS (2011), Dhaka experiences a hot, wet and tropical climate. The summer season commences in April and lasts up to July. The winter season starts in early November and lasts up to the middle of March. The minimum and maximum temperature during winter varies from $16.9^{\circ} \mathrm{C}$ to $22.2^{\circ} \mathrm{C}$. During the summer the minimum and maximum temperatures vary from $26.5^{\circ} \mathrm{C}$ to $30.6^{\circ} \mathrm{C}$. The heavy rainfalls are $345 \mathrm{~mm}$ and $314 \mathrm{~mm}$ during June and August, respectively. The average seasonal total rainfall in Aman season at Dhaka region is $1560 \mathrm{~mm}$. The average humidity varies from $62 \%$ to $96 \%$ in the Aman season.

\section{Sources and description of data}

Daily data of different climatic parameters such as maximum temperature $\left({ }^{\circ} \mathrm{C}\right)$, average humidity $(\%)$, total sunshine (hr) and seasonal total rainfall $(\mathrm{mm})$ at Dhaka station for the period of January 1970 to December 2012 (i.e. 43 years) were used in this study. Data were collected from Bangladesh Meteorological Department (BMD) and Bangladesh Agricultural Research Council (BARC). Investigation was carried out using the data of cultivated area (ha) and production $\left(\mathrm{t} \mathrm{ha}^{-1}\right)$ of Aman rice to find out the seasonal productivity. The yearly crop production data have been obtained from 'Yearbook of Agricultural Statistics of Bangladesh' of Bangladesh Bureau of Statistics (2012) from 1970 to 2012. The yield of different varieties of rice such as local and modern were used for present 
analysis. Crop-climate relationship was investigated on the basis of cropping season of rice. As the pre-sowing and post-harvesting period is important in terms of crop climate relation, therefore, the immediate preceding and succeeding months of crop life i.e. Jun to November for Aman rice was considered as operating periods for production as well as to show the changes in climatic parameters within this period.

\section{Variables considered}

Average seasonal maximum temperature $\left({ }^{\circ} \mathrm{C}\right)$ for Aman season was calculated from the average daily maximum temperatures of the cropping season. Total rainfall data, daily total sunshine hour and seasonal daily average humidity was calculated to analyze the trend and impact on the crop. The unit 'acre' of cultivated area was converted to 'hectare' (ha). The production unit 'metric ton' was converted to 'ton' $(\mathrm{t})$. Yearly annual yield ( $\mathrm{t}$ $\mathrm{ha}^{-1}$ ) was calculated dividing crop production by crop cultivation area.

\begin{abstract}
Analyses of data
After completion of data collection they were compiled, tabulated and analyzed according to the objectives of the study. Data were put in MS excel and SPSS for statistical analysis. Annual average and total measurement of the variables (temperature, relative humidity, sunshine, and rainfall) were calculated to analyze the trend and their correlation with yield $\left(\mathrm{t} \mathrm{ha}^{-1}\right)$ from 1970 to 2012. The regression equations and the coefficient of determinations $\left(\mathrm{R}^{2}\right)$ have been obtained through scatter diagrams by taking two variables at a time.
\end{abstract}

\section{Results and Discussion}

In the study four climatic parameters such as i) daily average maximum temperature $\left({ }^{\circ} \mathrm{C}\right)$, ii) seasonal total rainfall $(\mathrm{mm})$, iii) daily average humidity (\%), and iv) daily average sunshine (hr) were considered. The seasonal production of Aman rice was considered to find out its variability in production with the changes in climatic parameters.

\section{Annual production and area}

Fig.1 (a, $\mathrm{Y}_{1}$ axis) shows that the Aman rice production $\left(\mathrm{t} \mathrm{ha}{ }^{-1}\right)$ follows gradual increasing trend $\left(\mathrm{R}^{2}=0.79\right)$ at Dhaka region from 1970 to 2012. But the trend $\left(\mathrm{R}^{2}=0.75\right)$ of production area (ha) decreased during the study period. The production area started decreasing sharply after 1988 and the difference between the average annual production areas from 1970 to 1988 and 1989 to 2012 were 1258635.02 ha, indicates gradual loss of cultivated land. The production $\left(\mathrm{t} \mathrm{ha}^{-1}\right)$ and production area (ha) were inversely related with each other which indicates the development of production strategy, high yielding rice varieties and technology with increasing population and urbanization. The difference between the average annual production from 1970 to 1988 and 1989 to 2012 increased by 10129.49 $\mathrm{t} \mathrm{ha}^{-1}$ which can be described as the technological development such as irrigation system with high powerful machineries, high yielding varieties and uses of artificial fertilizers in the last three decades. In 2003, the production of Aman rice reached $2.35 \mathrm{t} \mathrm{ha}^{-1}$ which was the maximum in the studied 43 years and that's why the 2003 area bar is highlighted in the figure to investigate the variability of climatic variables more intensively.

\section{Annual rainfall}

The Fig.1 (a, $\mathrm{Y}_{2}$ axis) shows that the seasonal total rainfall followed random fluctuations in last 43 years. The coefficient of variation of the seasonal total rainfall was near to zero. In 2007, the yield of Aman rice was damaged by 14513 tonnes due to severe cyclonic storm SIDR and heavy rainfall (BBS, 2008) which were the devastating consequences of ongoing climate change scenarios.

\section{Average maximum temperature}

The Fig.1 (b, $\mathrm{Y}_{2}$ axis) shows the seasonal average of daily maximum temperature which shows moderate increasing trend $\left(\mathrm{R}^{2}=0.48\right)$, indicates an alarming threat in global warming point of view. Both the annual production $\left(\mathrm{t} \mathrm{ha}^{-1}\right)$ and average maximum temperature $\left({ }^{\circ} \mathrm{C}\right)$ were increasing gradually but the production area showed the decreasing trend. The difference between the average of daily maximum temperature from 1970 to 1985 and 1986 to 2012 increased by $0.87^{\circ} \mathrm{C}$ which can be described as a signal of regional warming in the last three decades.

\section{Average sunshine}

From the Fig.1 (c, $\mathrm{Y}_{2}$ axis), the seasonal average of daily sunshine shows a sharp decreasing trend $\left(\mathrm{R}^{2}=0.82\right)$ with some fluctuations. In spite of increasing trend of the production, both the annual production area and seasonal average of daily sunshine were decreasing which indicates the loss of cultivable land for Aman rice.

\section{Average humidity}

In Fig.1 ( $d, \mathrm{Y}_{2}$ axis), the seasonal average of daily humidity showed the moderate decreasing trend $\left(\mathrm{R}^{2}=0.62\right)$ with some fluctuations. The loss of humidity indicates drier condition which may cause grain shrinking (Amin et al., 2004). Though the production showed the increasing trend but both the production area and seasonal daily average humidity showed decreasing trend. The difference between the average humidity from 1970 to 1993 and 1994 to 2012 was decreased by $2.82 \%$ that may be caused due to destruction of water bodies and wetland by urbanization.

\section{Production year 2003}

The production year 2003 was chosen because the production $\left(\mathrm{t} \mathrm{ha}^{-1}\right)$ raised the highest peak. The Fig. 2(a) shows the seasonal (Aman season DN 153-335) variation between total rainfall and average humidity. The whole year data of daily rainfall and average humidity were taken to observe the pre and postseasonal conditions. The seasonal total rainfall was $2009 \mathrm{~mm}$ and the daily average humidity was $78.55 \%$. 


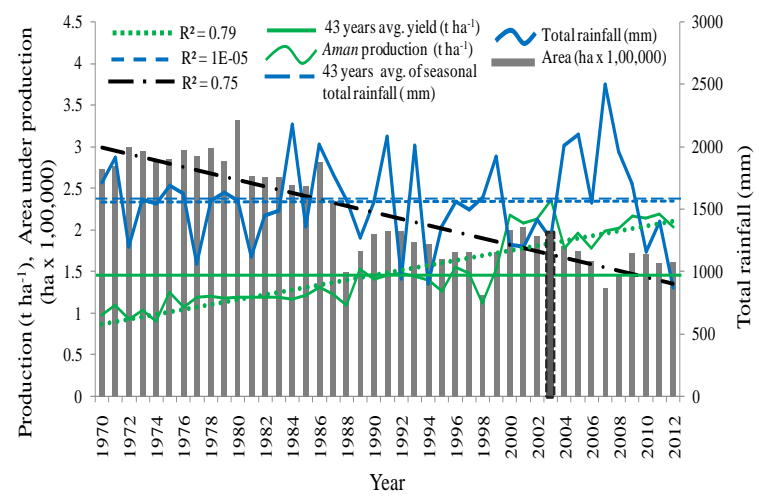

a) Total rainfall $(\mathrm{mm})$

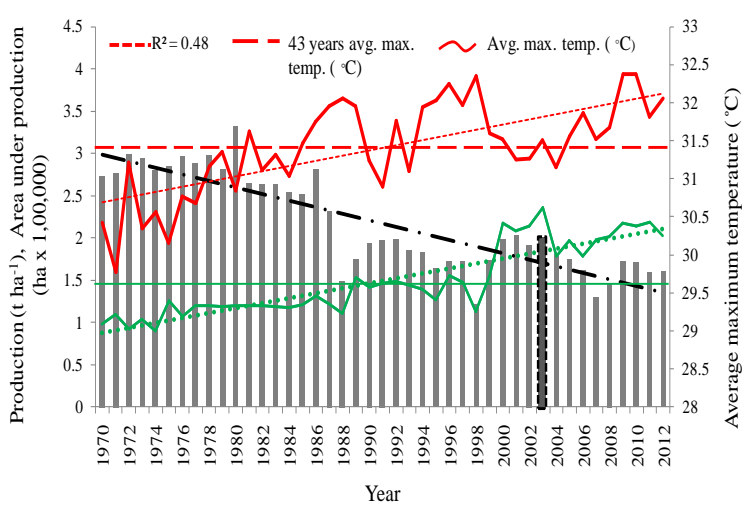

b) Average maximum temperature $\left({ }^{\circ} \mathrm{C}\right)$

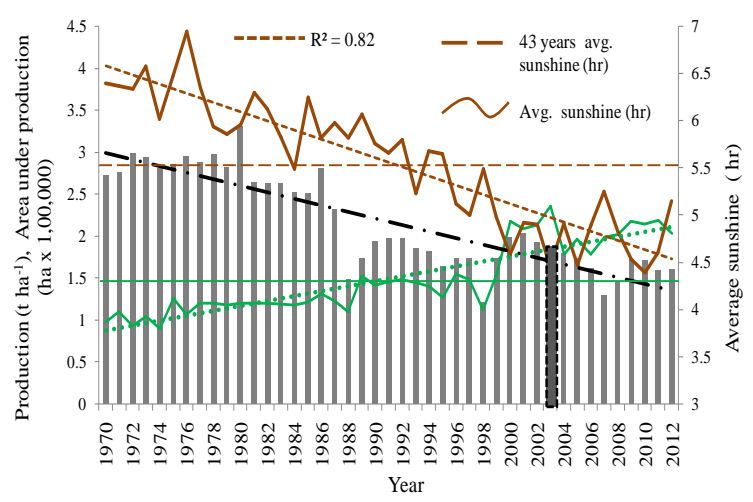

c) Average sunshine (hr)

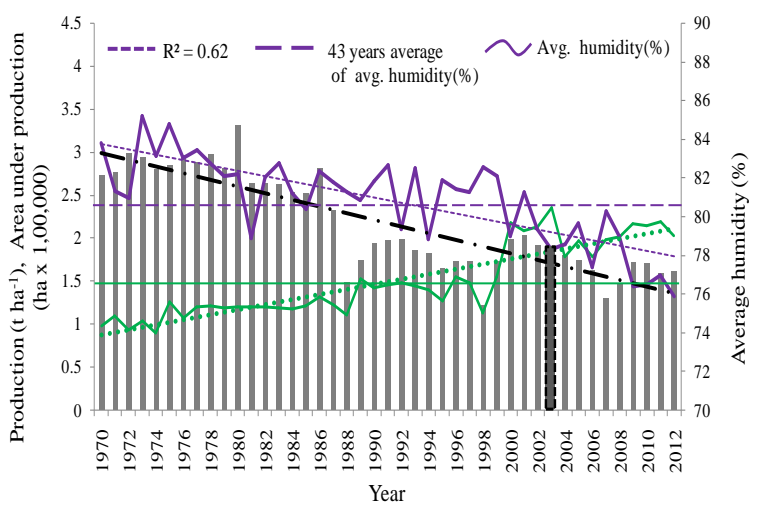

d) Average humidity ( \% )

Fig. 1. Interannual variability of Aman rice production with its production area at Dhaka region from 1970 to 2012 for a) total rainfall $(\mathrm{mm}), \mathrm{b})$ average maximum temperature $\left.\left({ }^{\circ} \mathrm{C}\right), \mathrm{c}\right)$ average sunshine $(\mathrm{hr})$ and d) average humidity $(\%)$

Fig. 2(b) shows seasonal (Aman season DN 153-335) variation between daily maximum temperature and daily sunshine. The rainfall fluctuated from $0 \mathrm{~mm}$ to $93 \mathrm{~mm}$, average humidity from $56 \%$ to $94 \%$, maximum temperature from $28{ }^{\circ} \mathrm{C}$ to $35^{\circ} \mathrm{C}$ and sunshine from 0 to

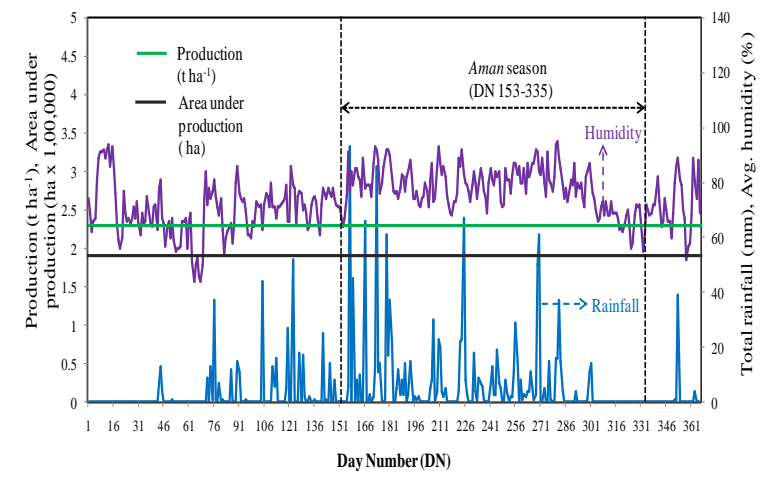

(a) Total rainfall and average humidity
$10.5 \mathrm{hr}$ in the season. Production in this year might have increased due to not occurring any natural calamities or extreme change of climatic variables in this season of the year.

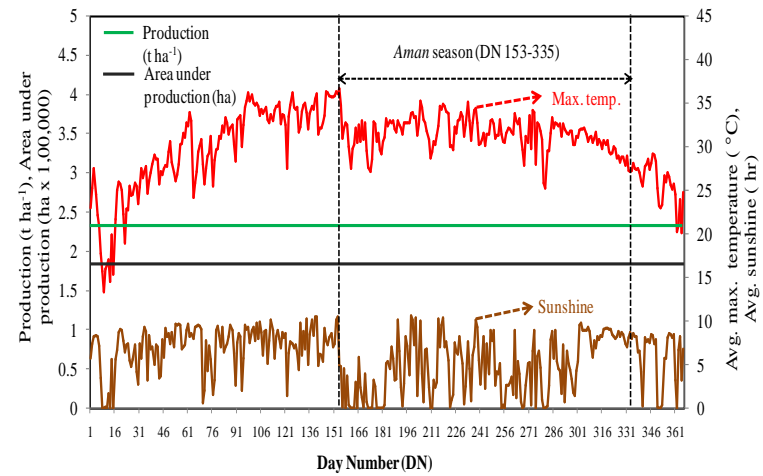

(b) Average maximum temperature and average sunshine

Fig. 2. Sesonal (Aman) variability between (a) total rainfall and average humidity, and b) daily average maximum temperature and daily average sunshine for the production year 2003 at Dhaka region

Relationship between Aman rice production $\left(t \mathrm{ha}^{-1}\right.$ ) and climatic variables
The seasonal production of Aman rice $\left(\mathrm{t} \mathrm{ha}^{-1}\right)$ is negatively correlated with average sunshine hours (Fig. $3 a)$ and correlated at $1 \%$ level $(r=-0.88)$ of significance 
(Table 1). The Fig. 3(a) shows that the production increases with the decrease of exposed times of sunshine that promotes photosynthesis rate. But the production increases with the decrease of sunshine hours which may be due to using of hybrid rice varieties, improved chemical fertilizers, modern technology etc. On the other hand, the seasonal production of Aman rice ( $\mathrm{t} \mathrm{ha}^{-1}$ ) is negatively correlated

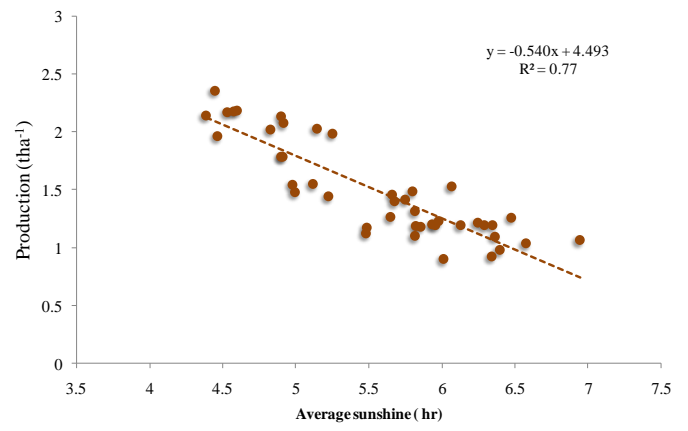

(a) Average sunshine (hr) with average humidity (\%) (Fig. 3b) and correlated at $1 \%$ level $(\mathrm{r}=-0.75)$ of significance (Table 1). The Fig. 3(b) shows that the production is increasing with the decreasing of average humidity that may be because of reduction of average humidity within the optimum range.

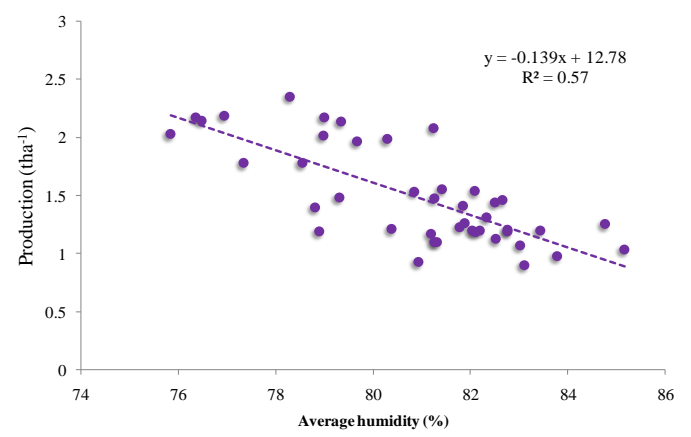

Average humidity $(\%)$

Fig. 3. Relationship between Aman rice production $\left(\mathrm{t} \mathrm{ha}^{-1}\right)$ with a) average sunshine (hr), and b) average humidity (\%) at Dhaka region from 1970 to 2012

Table 1. Climatic variables and seasonal productivity of Aman rice

\begin{tabular}{ccc}
\hline $\begin{array}{c}\text { Characteristics } \\
\text { correlated }\end{array}$ & $\begin{array}{c}\text { Co-efficient of } \\
\text { determination }\left(\mathrm{R}^{2}\right)\end{array}$ & $\begin{array}{c}\text { Correlation } \\
\text { co-efficient } \\
(\mathrm{r})\end{array}$ \\
\hline$S_{\text {avg }}$ Vs $\quad P$ & 0.77 & $-0.88(* *)$ \\
$H_{\text {avg }} V s \quad P$ & 0.57 & $-0.75(* *)$ \\
$T_{\max } V s \quad P$ & 0.20 & $0.44(* *)$ \\
\hline
\end{tabular}

(**) means significant at $1 \%$ level where,

$$
\begin{aligned}
S_{\text {avg }} & =\text { Average sunshine }(\mathrm{hr}) \\
H_{\text {avg }} & =\text { Average humidity }(\%) \\
T_{\max } & =\text { Average maximum temperature }
\end{aligned}
$$

\section{Conclusions}

The agro-climatic information is important for the solution of practical agricultural problems. This paper investigates the seasonal change of climatic variables and their correlation with the productivity of Aman rice at Dhaka region. The average sunshine hours and average humidity decreased by 0.05 and $0.14 \%$ in the season. The average maximum temperature and average seasonal rainfall increased slightly by $0.04^{\circ} \mathrm{C}$ and 0.09 $\mathrm{mm}$. The average production of Aman rice increased by $0.03 \mathrm{t} \mathrm{ha}^{-1}$ in the region. The seasonal productivity of Aman rice was mostly and inversely correlated with average sunshine. However, the crop production was hampered by the devastating floods during 1988 and 1998. This continuous change of climatic variables could affect the productivity of Aman rice. Therefore, more adaptive varieties of Aman rice for much production in near future will be needed under ongoing climate change scenarios in Bangladesh.

\section{References}

Adejuwon, S. A. 2004. Impact of climate variability and climate change on crop yield in Nigeria: A paper presented at the stakeholders workshop on assessment of impact and adaptation to climate change (AIAGG). pp. 2-8.

Amin, M. G. M.; Ali, M. H. and Islam, A. K. M. R. 2004. Agro-climatic analysis for crop planning in Bangladesh. Bangladesh J. Agri. Engg., 15 (1 \& 2): $1-40$.

Basak, J. K.; Ali, M. A.; Islam, M. N. and Alam, M. J. B. 2009. Assessment of the effect of climate change on Boro rice production in Bangladesh using CERES-Rice model, proceedings of the international conference on climate change impacts and adaptation strategies for Bangladesh, 18-20 February. pp. 103-113.

Basak, J. K.; Ali, M. A.; Islam, M. N. and Rashid, M. A. 2010. Assessment of the effect of climate change on boro rice production in Bangladesh using DSSAT model, pro-ceedings of the international conference on climate change impacts and adaptation strategies for Bangladesh. Journal of Civil Engineering (IEB), 38(2): 95-108.

BBS (Bangladesh Bureau of Statistics), 2008. Statistical Year book of Bangladesh. Bangladesh Bureau of Statistics. Ministry of Planning, Dhaka, Bangladesh. 188 p.

BBS (Bangladesh Bureau of Statistics), 2011. Statistical Year book of Bangladesh. Bangladesh Bureau of Statistics. Ministry of Planning, Dhaka, Bangladesh. 2 p.

Islam, M. S. and Morison, J. I. L. 1992. Influence of solar radiation and temperature on irrigated rice grain yield in Bangladesh. Field Crops Res., 30: 13-28.

Karim, A. J. M. S.; Rahman, A. K. M. H.; Egashira, K. and Haider, J. 1996. Yield and water requirement of Boro rice grown on a clay terrace soil of Bangladesh. Tropic. Agric. (Trinidad \& Tobago), 73(1): 14-1 